\title{
Some Points to Emphasize in Teaching the Geography of Africa
}

\section{Caroline W. Hotchkiss}

To cite this article: Caroline W. Hotchkiss (1912) Some Points to Emphasize in Teaching the Geography of Africa, Journal of Geography, 10:6, 177-184, DOI: $10.1080 / 00221341208985679$

To link to this article: http://dx.doi.org/10.1080/00221341208985679

曲 Published online: 20 May 2008.

Submit your article to this journal $\widetilde{ }$

Џ Article views: 2

Q View related articles $\longleftarrow$ 


\section{THE JOURNAL OF GEOGRAPIYY}

VOLUME X

FEBRUARY, 1912

NuMBER 6

\section{SOME POINTS TO EMPHASIZE IN TEACHING THE GEOG- RAPHY OF AFRICA}

By CAROLINE W. HOTCHKISS, Horace Mann School, New York City

$\mathrm{T}^{\mathrm{H}}$ years ago as the "Dark Contiment," has, during the last quarter of a century, been parcelled out among the powers of Europe. The same economic necessity which drove England, Holland, Spain, Portugal, and France in the sixteenth and seventeenth centuries to colonize the western world is forcing Great Britain, France, Germany, Italy, and Belgium to extend their influence overseas, until out of the eleven million square miles of Africa there is hardly a mile left which could be appropriated by any nation outside the charmed circle of the those already in possession. Here then is an opportunity to study political geography as it is being made in response to social and economic forces long at work, but only now focussed upon a stage which, for many centuries, has lain for the most part outside the ken of man.

To account for its past isolation.

To explain the why and the how of its recent partition and entry into world affairs.

To learn through this quest the characteristics of the chief coionies and "spheres of influence" are, I believe, the most important points to emphasize in the study of Africa. The recent move of Italy into Tripoli will suggest to many teachers a point of attack for this study.

\section{THE ISOLATION OF AFRICA}

The Sahara divides Africa into two parts. North of the desert lies the Mediterranean littoral, occupied by the white race, and practically a Mediterranean country. The real Africa lies south of the Sahara; here are the sweeping savannas, the dense jungles and forests, the fever haunted coasts, the Great Lakes, the Bush, and the Great Karroo; and here live the real African peoples. This portion of the continent has been virtually isolated from the great trade movements of the world. Though Egypt was 
the home of civilized races from the earliest ages of antiquity, its culture did not spread over the rest of the continent, shut off as it is on the landward side by a vast desert. Northern Africa has been occupied successively by Phoenicians, Greeks and Romans, but the civilization of these countries did not spread southwards because of the grim barrier of the Sahara. When the Arabs overran the country, they took advantage of the camel, which had been brought into Africa from Asia, and crossed the desert to the Niger, but they were blocked from further advance by the barrier of the dense forests. After ocean navigation became possible, the navigators of Western Europe felt their way along the western coast of Africa, touched Guinea, found gold, ivory, gums and spices, but did not go inland. On the da Gama route to India, Portuguese, Dutch and English ships used to put in for repairs at Table Bay, but for a long period they made no effort to push into the interior. Even in 1876, when the United States was celebrating the hundredth anniversary of her independence, it was thought unusual for a trader to go up the Congo as far as the Yellala Falls, ninetyfive miles inland, and, though a few explorers and missionaries had followed along the great rivers, of the vast interior of Africa south of the Atlas Mountains little was known. Why has so large a part of this continent remained for centuries a terra incognita? There are four main causes for this isolation:

1. Lack of means of communication with the interior

2. The unhealthiness of the coast lands

3. The small productive activity of the natives

4. The effects of the slave trade in discouraging legitimate commerce.

Though more than three times the size of Europe, the coast line of Africa measures only 16,100 miles as against 19,800 miles for Europe. Not an indentation to compare with the arms of the sea penetrating Western Europe! Not a gulf or bay worthy of the name on the whole coast! This monotonous coast-line not only hinders the trader from reaching the interior, it keeps out the tempering effects of the ocean, giving rise to vast inland spaces of monotonous climate and vegetation which have had a deterrent effect on the development of the continent. Travel between coast and interior is hindered by a plateau, fringed by a narrow coast zone of low land. It suffers from a monotony of surface as well as a monotony of coast-line and climate. There is no great amount of very high land, nor are there any great stretches of very low land; it is a continent of moderately elevated tablelands. Except for the Atlas Mountains, which are shut off from the main mass of the continent by the Sahara, there are no great mountain ranges as in Euro-Asia and the Americas. This tableland presents a high rim to the ocean except in the northeast. From the coastal lowlands the plateau rises in terrace-like steps to an average height of 
3500 feet. In most places the bordering rim is so near the coast that the rivers are obstructed by falls and rapids a short distance from their mouths, but by virtue of the railroads already built around the cataracts and rapids of the Nile, Congo, and Zambesi, and the placing of steamboats on rivers and lakes, this has almost disappeared. Stanley was eight months in reaching Victoria Nyanza from the Indian Ocean, but a governor of German East Africa recently left his capital at Dar es Salaam, traveled by steamer to Mombasa, from there by the Uganda Railroad to Victoria Nyanza, thence by steamer around its entire coast, and was back in his capital about a month after he left it.*

The coast of Siera Leone has long been known as "The White Man's Grave," and there are other stretches of these lowlands where the African fever is the dread of the European, but our great advance in knowledge of sanitation, and the destruction of the malarial mosquito, are enabling Europeans to live in regions once considered deadly. Where this zone is narrowest the highlands within easy reach with their lower temperatures and more bracing air play the part of sanitariums.

With regard to the fourth drawback to the development of Africa, the practical abolition of the slave trade has opened wider fields of commerce and industry, spurred the natives to something akin to activity, and established friendly relations between trader and producer.

The labor question is the most difficult of solution; but patience, example and education are already beginning to alter past conditions. Nearly all of tropical Africa is the black rnan's country, and the European colonizer must depend on him for manual labor. It is difficult to make some of the natives work, for a little labor secures all they need. But the Congo natives have been building the railroads around the rapids of the upper river, they have graded the road bed, burned the lime, and made the brick. They are locomotive engineers and firemen, they have become good carpenters and masons, and native tailoresses make garments on sewing machines for the thousands of black police, soldiers and workmen.*

\section{THE PARTITION OF AFRICA}

An examination of the political map of Africa shows it to be divided chiefly among the following nations-Great Britain, France, Germany, Belgium, Italy, Portugal and Spain. Northern Africa, including lower Egypt and the Barbary States, forming virtually part of the Euro-Asiatic continent, has been occupied by Phoenician, Greek, Rofian, Arab and Turk. Each has written his name on the map only to have it effaced by the next comer. France has just substituted the tri-color for the crescent in Algeria, Tunis, and, shall we say, Morocco? And the latest move of Italy in Tripoli threatens to wipe the Turkish color off the map of Africa.

*Foundations of Economic Progress in Tropical Africa, by Cyrus C. Adams. 
The partition of Tropical Africa began in 1879 with the explorations of Stanley in the Congo plateau. Since then each of five densely populated countries of Europe-France, Belgium, Great Britain, Germany and Italy-has painted her color over the black man's dominion with little more consideration for him than was shown to the red man in America three centuries ago. Why have these prosperous countries sought new lands in Africa? History repeats itself in the answer. Each wanted colonies

(1) to supply foodstuffs and raw materials. for home industries.

(2) for markets in which to sell home manufacturers.

(3) for new homes for the population of the already over-crowded mother country.

That the hopes of these countries for increased trade with their colonies is being realized is evidenced by some of the latest consular returns. The total export and import trade of Germany with German East Africa was $\$ 10,000,000$ in 1908; the total trade of French West Africa doubled in the ten years ending in 1908; the imports of the six British West African colonies were valued in 1908 at $\$ 3 \%, 000,000$, and exports at $\$ 35,000$,000 (approximated). Europe is looking to Africa for a new source of supply of maize; London markets are supplied with apples, pears and plums from South Africa; and there is no doubt that much of the world's future supply of cotton will come from British East Africa, German East Africa, the German Cameroons and Nigeria.

\section{POLITICAL DIVISION}

Italian Colonies.-Italy in Tripoli means that the Italians are coming into their own again, for in Roman days Tripoli was a profitable colony. It has an area as large as Illinois, Kansas, and Texas, with a population of about a million, composed chiefly of Berbers, Arabs, Turks and many Italians. Tripoli has no rivers worthy the name, and suffers from a long, hot, dry summer. Corn, barley, cattle and sheep are its chief products; while gold dust, ivory and feathers reach the Mediterranean through the three great caravan routes converging upon the Tripolitan coast. When the harbors are improved, the caravans policed, and the water now hidden in the sands poured upon the thirsty land, Italy may reap some profit from the acquisition of this new colony, and thereby reimburse herself for the disasters she suffred in connection with her colonies on the Red Sea and in Somaliland.

French Colonies.-Since 1870 France has been quietly at work building an empire in Africa, till now she has acquired the lion's share of the continent. The territory which France controls is one and one-half times that of the United States, and stretches from the banks of the Congo to the Mediterranean, and from the Atlantic Ocean to the valley of the Nile, except a few patches of British and Spanish territory on the west coast, 
and the British and German colonies on the coast of Guinea. In East Africa France has Madagascar and French Somaliland.

In extending civilization over West Africa, France has built 6,000 miles of railroad, 25,000 miles of telegraph, and 10,000 miles of telephone. You can buy in Paris a round trip ticket to Timbuctoo, and reach all parts of the world from there by telegraph.

A railroad is being pushed across the Sahara to Timbuctoo and Lake Tchad, the former to connect with the line from Dakar on the Atlantic coast. Camel police guard the caravans, which are often moving cities. Darkar, the capital of Senegal, is the seat of the government of French West Africa and the chief seaport. It is a city of some 25,000 population, and looks like a French town, with its shaded boulevards and magnificent public buildings. In all this territory the French govern 12,000,000 of the more enlightened natives of Arica. The chief products of the West Coast and French Guinea are palm kernels (for oil), rubber, gum, gold, ivory, mahogany, and ground nuts. The Sahara, like our great American Desert of thirty years ago, has a supply of underground water, and what we have done through irrigation in Arizona and New Mexico, may be repeated there. Its surface is elevated, rising into a high plateau with peaks of 8,000 feet altitude. It is dotted with fertile oases. The French are working patiently at the water problem, planting schools and hospitals, and introducing the American phonograph and sewing-mchine along with the railroads. Algeria is her most profitable colony; it is now well governed, and the city of Algiers has become a winter resort for Europeans.

British Colonies.-The territory under British control stretches with but a single break (German. East Africa) from the mouths of the Nile to Cape of Good Hope. In 1795 England captured the Cape to use as a halfway house to India. The Dutch had settled there, but neither nation then knew of the gold in the rocks of the Transvaal, or of the diamonds at Kimberley. Then Egypt came under the British "sphere of influence," and when the Suez Canal was built, her fate was sealed. Now England is rorking to cement her vast colonial empire in Africa by building a railroad from the Cape to Cairo. From Alexandria it runs past the Pyramids, past the great dam at Assouan to Khartoum, and on to Sennar on the Blue Nile. The southern end starts from the Victoria Station in Cape Town, climbs up the Great Karroo, skirts the Kalahari Desert to Kimberley, reaches Bulawayo in Matabeleland, crosses the Zambesi at Victoria Falls, (over twice the height of Niagara) on into Northern Rhodesia to Broken Hill, the present terminus of the line, and about 2,000 miles from Cape Town. The whole line will be 6,870 miles long; about three-fourths of it is completed. When the northern end reaches Victoria Syanza, and the southern end Lake Tanganyika, there may come a halt, for between the two lies German East Africa. Will Germany grant Englaud right of way? 
Germany may ask for Walfish Bay in return, as it is the only good harbor in Southwest Africa and is an aggravating patch of British territory in the midst of German possessions.

Egypt consists of the Nile and the desert. It would be all Sahara if it were not for the Nile. It is one of the important trade routes of the world, and, though nominally under Turkish rule, British influence predominates. The Nile is navigable throughout its course in Egypt, and is used for the transit of heavy goods. Only the land watered by the river can be cultivated, but modern engineering skill is bringing larger areas under irrigation. The largest dam in the world has been built at Assouan, forming a storage lake in the Nile 200 miles long.

Egypt is the third cotton-producing country of the world. All her other exports are of minor importance compared with cotton. Great Britain is her largest customer; she spins the cotton fibre and sends back to Egypt cotton cloth, the largest import of the country. Egypt has sugarmills and flour-mills, makes cigarettes and beautiful water-jars. Many of the cities are built on the ruins of ancient towns, for Egypt was old when London was a cluster of mud huts. Its mild winters and dry climate, its famous monuments and ruins attract many tourists. About 40,000 pilgrims on their way to Mecca pass every year through the Suez Canal; of the 4,000 ships which paid their toll in 1905, one-half carried the English flag.

South Africa. The discovery of gold near Johannesburg, and of diamonds at Kimberly, brought a rush of immigrants into the country, as into our West in 1849; Johannesburg is now an important railroad center for lines radiating to Cape Town, Durban, and Lourenco Marques. But the settlers are finding that the true gold is in the soil and in the cultivation of the soil. Up from the coast lies the veld-the Great Plains of South Africa. The Great Karroo is a vast arid stretch with no grass and no trees, but with succulent shrubs and brushes. The soil is rich, the air clear and bracing, with warm days and cold nights. Karroo farmers love their landscape and lonely life. A few days' rain makes the dry Bush land like a garden, covered with flowers. On the veld grow the grasses which support cattle, sheep and goats. Next to the wool crop the chief product is ostrich plumes. Farms are great ranches, population scanty as in the plains of Argentina and in Montana and North Dakota. Many of the rivers are intermittent like the Platte in Kansas; roaring floods when it rains, but in the dry season chocked with sand. On the plateau the climate is well suited to Europeans. Here the Boer farmers trekked after the English captured Cape Colony, and they still form a large part of the population. Natal is the "Garden of South Africa." Apples, plums, and other fruits find a market in London and in the United States; ripening, as they do, in our winter they bring a good price. From the coasts raillroads climb 
up steep grades into the interior, to the mining regions in the Transvaal; and at Cape Town, Port Elizabeth and Durban the originally poor harbors have been improved.

British East Africa and German East Africa have many features in common. The plains rise gradually from the coast. Here are white settlers, raising cattle, sheep and horses, like our farmers in western Nebraska and Texas. On these grasslands roam the big game, as did the buffalo of our western country. Experiments are being tried in the raising of cotton, alfalfa, fruits, and vegetables. From Mombasa the English have built a railroad to Victoria Nyanza, and the Germans are pushing a line from Dar es Salaam to Lake Tanganyika; the latter will strike the lake at Ujiji where Stanley found Livingstone.

German Colonies.-Besides German East Africa, Germany owns the Cameroons and Togoland on the Gulf of Guinea and German Southwest Africa. The same zones of surface, climate and vegetation are here, as elsewhere in Africa. In Togoland and the Cameroons, as in German and British East Africa, much money is being spent on cotton cultivation. These regions are possible rivals of the United States in the cotton trade. Germany would like to supply her mills from her own colonies. From Southwest Africa the Germans are building a railroad which will eventually connect with the line from Dar es Salaam, bringing the two separated parts of Germany's colonial empire together.

The Belgian Congo.- The Congo River is the outlet of this state in the heart of Central Africa. Stanley Pool, at the head of the rapids, is a center for the collection of rubber, ivory and copal gum from the interior, and many warehouses of foreign nations are built along the banks of the river above this point. Railroads run around the falls and rapids, and in the upper river there are nearly one thousand miles of continuous navigation; so the river is a great commercial highway and many steamboats carry products to the centers of distribution. The forests of the upper Congo rank with those of the Amazon; they are dark and almost impenetrable-veritable jungles threaded by footpaths. The river is second in volume to the Amazon. Both rivers are visited by a vertical sun twice a year, hence both are regions of heavy rainfall. Owing to the elevation of the interior of the Belgian Congo, it offers greater inducement to the European settler and trader than does the Amazon valley. The slitre trade has been abolished, but the supply of ivory is diminishing. We have had to invent a substitute for it.

\section{CLIMATE AND ITS EFFECTS}

Africa is a country of small rainfall, except in equatorial regions. There the vertical sun occurs twice every year and the consequent heary rainfall gives rise to the Niger, Congo, Nile and Zambesi rivers, and to the 
dense, jungle-like forests. Where rains occur but once a year the forests are less dense. The climate and vegetation north of the equatorial belt repeats itself south; the grasslands succeed the forests north and south, then come the desert belts, though the Sahara is drier than the Kalahari on account of the great land mass north and east. The climate and vegetation north of the Atlas is Mediterranean in character; that of South Africa is similar to Australia in the same latitude. On the southeast of each continent there is abundant rainfall, lessening towards the interior; the tropical and semi-tropical vegetation of the coast gives place to the arid growth of a temperate climate. North and south of the Atlas Mountains there is a similiar change in rainfall and vegetation.

\title{
SUGGESTED MODIFICATIONS IN HIGH SCHOOL GEOGRAPHY
}

\author{
By R. H. WHITBECK, \\ University of Wisconsin, Madison
}

T $N$ many places, physical geography is being placed on the defensive. It is claimed that the study is unduly technical and not sufficiently practical. If it has not been found that it contributes as much in the way of training and practical information as a study ought to contribute, then surely physical geography ought to be modified or give place to some other study. Most friends of physical geography agree that the study must be somewhat modified if it meets the reasonable demands which are now imposed upon any study in the high school. For the high school courses are more than crowded. Our complex life seems to demand such a variety of studies that any branch which cannot clearly justify its place in the curriculum must give way.

During the last few years the demands made by the friends of vocational training have been very insistent. One group of people is urging that agriculture be taught in the high schools, another, domestic science, a third, manual training, and so on. All of these studies are capable of vigorous defense. All of them promise definite and practical training, and their claims cannot be dismissed.

Physical geography is about the only study in the first year of the high school that can be readily displaced. English must be retained. Most people believe that algebra must be retained. Many would not consent to have history taken out of the course. Tatin, if studied, should begin in the first year of the high school. Thus it comes about that in the pressure which is being brought to bear, physical geography is the study which is most likely to yield, and unless we can show clearly that it is capable of giving the pupil more valuable information or more effective train-

*Abridged from an address given before the Earth Science Section of Central Association of Science and Mathematics Teachers, Chicago, Dec, 2, 1911. 